\title{
Augmented Reality-assisted Pictorial Storybook: Media to Enhance Discipline Character of Primary School Students
}

\author{
Azmil Hasan Lubis ${ }^{\bowtie 1}$ \& Muhammad Nur Wangid² \\ 1,2 Pendidikan Dasar, Program Pascasarjana, Universitas Negeri Yogyakarta \\ $\bowtie$ azmil.hasan2016@student.uny.ac.id
}

\begin{abstract}
This research is intended to determine the effectiveness of Augmented Reality (AR)assisted pictorial storybook in improving discipline character of primary school students. The population of this research was all state-run primary schools in in Sleman Regency, Special Region of Yogyakarta, Indonesia. Specifically, the samples were fourth-grade students from two primary schools, where each of them was selected to be control and experiment groups. The method used is an experimental research, while the sampling technique was cluster random sampling technique. The data collection technique was disciplinary character observation technique. Furthermore, the data were analyzed using t-test technique. The results of this research indicated that the value of sig. t-test was $0.00(<0.05)$. Thus, it can be concluded that AR-assisted picture storybook was considered effective in enhancing disciplinary character of primary school students. Therefore, it is recommended that the use of AR can be improved and disseminated to reach the learning objectives of primary school students, specifically in enhancing discipline character.
\end{abstract}

Keywords: Augmented Reality, discipline characters, pictorial storybooks, primary school students.

How to Cite: Lubis, A., \& Wangid, M. (2019). Augmented Reality-assisted Picture Storybook: Media to Enhance Discipline Character of Primary School Students. Mimbar Sekolah Dasar, 6(1), 11-20. doi:http://dx.doi.org/10.17509/mimbar-sd.v6i1.16415.

INTRODUCTION School is a medium to

instill discipline character in students. To facilitate formal education for students, schools should provide education that can shape students' character. The role given is in the form of education to provide moral knowledge, feelings, and behavior (Lickona, 1991). This emphasizes the importance of giving character education to students. It is essential to instill the character during primary school (SD, Sekolah Dasar) because it is the most effective period to shape students' character (Duckworth, 2009). Various efforts should be made and among many types of important characters, discipline character is included.

Discipline character is essential to be possessed by students so they live in order. Students who have the discipline character will have better knowledge and performance than students who do not (Duckworth \& Seligman, 2005). This is because being discipline makes a person always try to follow the established procedures by obeying existing rules and always being careful in doing things. This attitude will generate maximum result in everything they do. In the context of learning, discipline students tend to follow 
Azmil Hasan Lubis \& Muhammad Nur Wangid, Augmented Reality-assisted Picture Storybook...

the learning process and complete the assignments well.

There are efforts to improve students' discipline character. First, instilling the discipline character by teacher and parents. This is in accordance with the research by Letarte, Normandeau \& Allard (2010) stating that parenting by familiarizing children with discipline is very effective. In addition, Osher, Bear, Sprague \& Doyle (2010) explained that the rules given in the school environment and in the classroom environment in learning can shape students' discipline. This was reinforced by Nurjaman and Julia (2018) stating that character building in elementary school students could be done through habituation at school. The treatment can also be given by the teachers to students in an effort to instill a discipline character through the Subject Specific Pedagogy (Apriani \& Wangid, 2015). Therefore, the role of parents and teachers becomes very important to instill the discipline character in students. Second, using learning media through children's literature. This is in accordance with the research by Kelemen, Emmons, Seston Schillaci \& Ganea (2014) and Emmons, Smith \& Kelemen (2016) stating that use of picture storybook can be used to instill attitudes or characters to students.

Not many studies on the use of pictorial storybooks in improving students' discipline character have been conducted, especially by using AR feature. Hence, this research seeks to determine the effectiveness of AR-assisted pictorial storybooks in improving students' discipline character.

Discipline character is a trait that a person has to obey rules, maintain order, always on time, and always considering risks in doing everything (Nucci \& Narvaez, 2014). A student who has discipline character would obey the rules that apply in school and in the classroom, be orderly when taking lessons, be on time, and be careful in doing work to avoid negative risks. Considering this notion, this research focuses on three indicators, namely obedient, orderly and thorough.

Pictorial storybooks can be used by teachers to instill discipline character to students. Pictorial stories are a combination of text and interlocking images that explain the meaning of presented stories (Huck, 1987; Brown \& Tomlinson 1999). Furthermore, Mitchell (2003) reveals that through pictorial storybooks, children's character would be formed. This is obtained from the moral messages contained in the story. It explains that pictorial storybooks can be used as one of the media to improve students' discipline. The moral messages contained in the story can teach students the importance of being discipline and the overview of the life or can provide students with a better understanding of the content. This is in accordance with the opinion of Halimatussadiah (2017) stating that the presentation of students' real life 
stories (contextual) has a good influence on the students' understanding process.

Learning media that can attract students' attention will play a more maximal role in achieving learning goals (Sunaengsih, 2016). This is in accordance with the opinion of Heinich, Molenda, Russell \& Smaldino (2002) stating that learning media serves to attract students' attention. Therefore, learning media should provide a special attraction for students. Based on the opinion, interesting pictorial storybook can be effectively used to instill discipline character. Adding AR features into pictorial storybooks is one way to attract students' attention. This is in accordance with the opinion of Lee (2012) stating that the application of technological developments in the form of AR in learning activities can attract attention and then will encourage students to take part in learning. Furthermore, the appearance of real images in $A R$ features will attract students' interest.

$A R$ is one of the technological developments in the virtual realm that can display abstract images that become real and life-like (Craig, 2013). This feature can be used in pictorial storybooks, so that abstract images can be presented concretely to students as readers. The pictorial storybook used in this research is a storybook that assisted by AR features. The addition of AR features is intended to help students understand the images and make pictorial storybooks more interesting.
In addition to building understanding of abstract images as they are in a concrete operational period (Woolfolk, 2016), the presence of $A R$ features also attracting students' attention. When this successfully makes students interested in learning, students will be more eager to finish reading the book and will get an example of the characters role and messages of the story. Thus, the efforts to instill discipline in students through AR-assisted pictorial storybooks are expected to work effectively.

Based on the aforementioned explanation, it is necessary to test the effectiveness of AR-assisted pictorial storybook in improving students' discipline character.

\section{METHODS}

This research employs quantitative approach with pre-test/post-test control group design. There are two randomly selected groups, but assumed to have the same characteristics (homogeneous). One group became the experimental group and the other group became the control group. Both groups followed the lesson as usual, and then the initial observation (pretest) was conducted to determine students' discipline character before receiving treatment. After that, the two groups followed the lesson with different treatments, then the observations (posttest) were conducted during the learning process. The implementation of the observations was conducted using the 
Azmil Hasan Lubis \& Muhammad Nur Wangid, Augmented Reality-assisted Picture Storybook...

time series method with the provisions of four times pre-tests and four times posttest. Furthermore, the average pre-test and post-test scores were taken. Then, the data obtained were analyzed.

This research was conducted in Berbah Subdistrict, Sleman, Yogyakarta. The population of was all state-run primary school students in Berbah Sub-District, Sleman, Yogyakarta, consisting of 24 primary schools. The sampling technique used in this research was cluster random sampling. The samples were fourth-grade students from two primary schools. The fourth-grade students of the first primary school were the experimental group who were exposed to AR-assisted pictorial storybooks. Meanwhile, the fourth-grade students of the second primary school were the control group who were exposed to ordinary picture. The experimental group consisted of 30 students 13 males and 17 females) and the control group consisted of 30 students 11 males and 19 females).

The variables of this research are ARassisted pictorial storybooks (variable $X$ ) and discipline characters (variable $Y$ ). Data collection techniques were conducted by observing students' discipline characters and using observation sheets as data collection instruments. The observation sheet in this research used a 1-4 scale range. The data obtained were analyzed and interpreted. The research instrument validity was checked by the help of expert judgment, namely character education expert. After the instrument was declared valid, the reliability test was conducted, where the instrument reliability was tested using Cronbach's alpha.

This research went through several stages:(1) conducting a preliminary research in the school; (2) compiling research instruments; (3) performing pretest observations of discipline character; (4) giving treatment to the experimental group using AR-assisted pictorial storybooks and control groups using images on the learning process of the same material; (5) performing post-test of discipline character observations; and (6) analyzing the data.

The obtained quantitative data were analyzed using descriptive statistics and inferential statistics. Descriptive statistical analysis was used to present and describe the data obtained from the pre-test and post-test in the experimental group and the control group. Descriptive analysis was used as a comparison of each group discipline character scores. Furthermore, the categorization of data was conducted through the score table obtained from each group. Inferential statistical analysis was conducted to determine the differential significance between the experimental group and the control group, to generalize the result of this research. Inferential statistical analysis in this research used paired test analysis and independent t-test with the help of the SPSS 22.0 application. 


\section{FINDING AND DISCUSSION}

The results of the descriptive analysis of the pre-test/post-test in the experimental and the control group showed an increase in the average score of students' discipline character. It indicated that the average pre-test score of students in the experimental group was 33.87 and then increased to 44.10 in the post-test. An increase in the average score of student acquisition in the experimental group was 10.23. Whereas, in the control group, the average pre-test value was 33.90 and increased to 35.87 in the post-test. An increase in the average score of student acquisition in the control group was 1.97 in the post-test. Based on these data, it could be seen that the increase in the average score of students' discipline in the experimental group was higher than the increase in the control group. This meant that students who took part in learning using AR-assisted pictorial storybooks had an increase in the discipline character average score that was better than students who did not.

Furthermore, the data were presented in a table to determine the tendency of the pre-test and post-test scores in the experimental group and the control group. The following Table 1 shows the tendency of the pre-test and post-test scores of the experimental group and the control group discipline character.

Table 1. The Tendency of Discipline Character Score.

\begin{tabular}{cccccc}
\hline \multirow{2}{*}{ Group } & \multirow{2}{*}{ Criteria } & \multicolumn{2}{c}{ Pre-test } & \multicolumn{2}{c}{ Post-test } \\
\cline { 2 - 6 } & Very High & $\mathbf{F}$ & $\mathbf{\%}$ & $\mathbf{F}$ & $\%$ \\
\hline \multirow{3}{*}{ Experimental Group } & 0 & 0.00 & 5 & 16.67 \\
\cline { 2 - 6 } & High & 3 & 10.00 & 23 & 76.67 \\
\cline { 2 - 6 } & Low & 26 & 86.67 & 2 & 6.67 \\
\cline { 2 - 6 } Control Group & Very Low & 1 & 3.33 & 0 & 0.00 \\
\cline { 2 - 6 } & Very High & 0 & 0.00 & 0 & 0.00 \\
\cline { 2 - 6 } & High & 5 & 16.67 & 9 & 30.00 \\
\cline { 2 - 6 } & Low & 22 & 73.33 & 21 & 70.00 \\
\cline { 2 - 6 } & Very Low & 3 & 10.00 & 0 & 0.00 \\
\hline
\end{tabular}

Table 1 shows that, in general, there was an increased in the experimental group, but not in the control group. The data from the experimental group's pre-test showed that $86.67 \%$ students' discipline scores tended to be low. In the post-test, the tendency of the experimental group's discipline character scores increased, where $76.67 \%$ of students were in the high category. Whereas in the control group, the results of the pre-test showed that 73.3\% of students' discipline character scores tended to be low.. Furthermore, the post-test scores in the control group did not show an increase, where $70.00 \%$ of 
Azmil Hasan Lubis \& Muhammad Nur Wangid, Augmented Reality-assisted Picture Storybook...

students' discipline character acquisition scores still tended to be low.

After conducting descriptive statistical analysis, inferential statistical tests were conducted to generalize the data. Disciplinary inferential statistical tests used were paired t-test and independent t-test. Before conducting the t-test, a prerequisite test for normality and homogeneity was conducted on the data obtained. The results of the normality test showed the Sig. $>0.05$ ( $\mathrm{HO}$ is accepted). Therefore, it could be concluded that the data were normally distributed. The homogeneity test results showed the Sig. $>0.05 \quad \mathrm{HO}$ is accepted), which meant that the data came from a homogeneous population. Thus, the data had fulfilled the prerequisite test to perform the t-test.
The first t-test conducted was a paired ttest to discover whether there were differences in students' discipline character before learning by using ARassisted pictorial storybooks and afterwards. The paired t-test results showed that the Sig 2-Tailed value was $0.00(<0.05)$, which meant that there were differences in students' discipline character before and after learning using AR-assisted pictorial storybooks.

Furthermore, an independent t-test was conducted to discover whether there were differences between students who took part in learning using AR-assisted pictorial storybooks and those who did not. The following Table 2 shows the independent t-test results on observational data on students' discipline character.

Table 2. The Result of Independent T-Test.

\begin{tabular}{llll}
\hline \multirow{2}{*}{ Variable } & \multicolumn{2}{l}{ Equal variances assumed } & Note \\
\cline { 2 - 3 } & Sig. (2-tailed) & Asymp. & \\
\hline Discipline Character & 0.000 & Sig. $<0.05$ & There is a difference \\
\hline
\end{tabular}

Table 2 shows the result of the independent t-test. The Sig 2-Tailed value was $0.00 \quad(<0.05)$. Hence, there were differences in the discipline character of students who took mathematics learning using AR-assisted pictorial storybooks, compared to students who did not The discipline indicators in this research consisted of three aspects, namely (1) obeying the existing rules; (2) following the learning process orderly; and (3) doing something carefully. This is consistent with the opinion of Curwin, Mendler \& Mendler
(2008) and Komalasari \& Saripudin (2017) stating that the discipline of a child can be seen from the order of life. The order included obedience to the applicable rules, maintaining order, and being careful in acting. The use of AR-assisted pictorial storybooks in an effort to improve the discipline character of fourth-grade students in primary school in this research was appropriate. These findings are in accordance with the opinion of Djuanda (2014) stating that giving stories was very 
appropriate for students in grade four of primary school.

The results of this research indicated that AR-assisted pictorial storybooks could improve students' discipline character in learning. This finding is in accordance with the opinion of Almerico (2014) and Bohlin (2005) stating that students' character can be formed through habituation of students who were brought closer to a literary work in the form of a storybook. The opinion of Almerico and Bohlin was reinforced by the opinion of Duckworth (2009) stating that primary school was the right time to instill the discipline character, one of which was through storybooks. The formation of the character was derived from the reinforcement in the story, both in the role of the character and the message of the story. These findings are also supported by the opinion of Mallet (2010) stating that the strength of a story lies in how much influence the story had to create positive behavior. Positive behavior was the formation of a good attitude.

Increasing students' discipline character through the AR-assisted pictorial storybooks was obtained from (1) characterization of the characters; (2) the message of the story; and (3) AR features in the storybooks. This finding is in accordance with the results of research conducted by Saputro \& Soeharto (2015) stating that children's literature has a role to play and the message of stories that can help to shape students' character. The role of the characters in the story could motivate students to imitate it and the message of the story gave moral lesson. So, the discipline characters can be embedded in students through a literary work. Furthermore, Chen, Lee \& Lin (2016) stated that the addition of $A R$ features could be used as a way to attract students' attention, so that they could enjoy and understand the contents of the stories.

\section{Character}

Characterization or role of the characters in the story could give students insight into the importance of instilling the discipline character in themselves. The role of the figure who gets ease in solving his problems while being discipline could be used as an example. This was in accordance with the opinion of Gilang, Sihombing, and Sari (2017) and Matulka (2008) stating that in a story, there was a role from a character that can be used by children as an example in instilling good character. This opinion showed the importance the character in influencing students as readers. The influence made the students imitate it. Thus, the discipline character played by the characters in the story will easily be instilled in students. These findings are also reinforced by the results of the research by Tetenbaum \& Pearson (1989) stating that character formation could be done by presenting the role of the characters in the story, it could relatively influence the reader which they will eventually emulate as an example. 
Azmil Hasan Lubis \& Muhammad Nur Wangid, Augmented Reality-assisted Picture Storybook...

\section{The Message of the Story}

The message contained in the AR-assisted pictorial storybook helped to improve students' discipline character. It gave a lesson to students that children who were discipline will have a more regular life than those who were not. So, through the message, students understood how important it was to instill the character in themselves. This is in accordance with the opinion of Huck (1987), Munaris (2011), and Setyawan, Suwandi, and Slamet (2017) stating that by reading a story, students will receive moral messages that can help them instilling their discipline character. So, the students will be motivated to instill the discipline character within themselves. The role of the teacher to bridge the message was needed to provide reinforcement towards achieving the goals. This was in accordance with the opinion of Sheldon \& Epstein (2002) stating that collaboration between the school and parents could facilitate the formation of students' discipline character.

\section{Augmented Reality Feature}

The AR feature on pictorial storybooks attracted students' interested in reading all parts of the book. This is consistent with the results of a research conducted by Cuendet, Bonnard, Do-Lenh \& Dillenbourg (2013) stating that AR features presented to students through pictorial storybook were able to attract students' attention. Hence, they were increasingly curious about the contents of the book given.
These findings were also reinforced by research conducted by O'Shea (2011) stating that the presence of AR features visualized images in flat fields to be more real. In addition to attracting the attention of users, it could also ease users to understand the images displayed. In the context of this pictorial storybook, the advantages of the AR feature can be used as one of the attractions of storybooks that could make readers more interested in the content of the stories.

The results of this research has provided additional insight to the knowledge of one medium of learning that was effective in improving the discipline character of primary school students. The application of AR-assisted pictorial storybooks could shape students' character easing teachers to instill discipline in students.

\section{CONCLUSION}

Based on the aforementioned research findings and discussion, it can be concluded that AR-assisted pictorial storybooks had a positive and significant effect on students' discipline the character. Therefore, it can be concluded that (1) there were differences in the character of the discipline before and after students learned using AR-assisted pictorial storybook; (2) there were differences between students learned using AR-assisted pictorial storybooks and those that did not. Therefore, it is recommended that the use of AR can be improved and disseminated to reach the 
learning objectives of primary school students, specifically in enhancing discipline character.

\section{REFERENCES}

Almerico, G. M. (2014). Building Character Through Literacy with Children's Literature. Research in Higher Education Journal, 26(2), 1-13. Retrieved from http://www.aabri.com/copyright.html.

Apriani, A., \& Wangid, M. N. (2015). Pengaruh SSP Tematik-Integratif terhadap Karakter Disiplin dan Tanggung Jawab Siswa Kelas III SD. Jurnal Prima Edukasia. 3(1). 12-25.

Bohlin, K. E. (2005). Teaching Character Education trough Literature: Awakening the Moral Imagination in Secondary Classroom. New York: Roudledge Falmer.

Brown, C. L., \& Tomlinson, C. M. (1999). Essential of Children's Literature (3rd ed.). New York: Allyn \& Bacon A Vlacom Company.

Chen, C.-H., Lee, I.-J., \& Lin, L.-Y. (2016). Augmented Reality-Based VideoModeling Storybook of Nonverbal Facial Cues for Children with Autism Spectrum Disorder to Improve Their Perceptions and Judgments of Facial Expressions and Emotions. Computers in Human Behavior, 55, 477-485. doi:10.1016/j.chb.2015.09.033

Cuendet, S., Bonnard, Q., Do-Lenh, S., \& Dillenbourg, P. (2013). Designing augmented reality for the classroom. Computers \& Education, 68, 557-569. doi:10.1016/j.compedu.2013.02.015.

Craig, A. B. (2013). Understanding Augmented Reality: Concept and Application. Waltham: Elsevier.

Curwin, R. L., Mendler, A. N., \& Mendler, B. D. (2008). Discipline with Dignity: New Challenges New Solutions (3rd ed.). Alexandria: ASCD Member Book.

Djuanda, D. (2014). Pembelajaran Sastra di SD dalam Gamitan Kurikulum 2013.
Jurnal Mimbar Sekolah Dasar. 1(20). 191-200.

Duckworth, A. L., \& Seligman, M. E. P. (2005). Self-Discipline Outdoes IQ in Predicting Academic Performance of Adolescents. Psychological Science, 16(12), 939-944. doi:10.1111/j.1467$9280.2005 .01641 . x$

Duckworth, A. L. (2009). Self-Discipline is Empowering. Phi Delta Kappan, 90 (7), 536,

https://doi.org/10.1177/0031721709090 00720.

Emmons, N., Smith, H., \& Kelemen, D. (2016). Changing Minds With the Story of Adaptation: Strategies for Teaching Young Children About Natural Selection. Early Education and Development, 27(8), 1205-1221. doi:10.1080/10409289.2016.1169823.

Gilang, L., Sihombing, R. M., \& Sari, N. (2017). Kesesuaian Konteks dan llustrasi pada Buku Bergambar untuk Mendidik Karakter Anak Usia Dini. Jurnal Pendidikan Karakter. 7(2). 158169.

Halimatussadiah, A. M. A. (2017). Pengaruh Pendekatan Kontekstual Berstrategi REACT terhadap Kemampuan Pemahaman Matematis dan Motivasi Belajar Siswa Sekolah Dasar. Jurnal Mimbar Sekolah Dasar. 4(3). 203-2017. DOI: $\quad$ 10.17509/mimbar-sd.v4i3.7766. http://ejournal.upi.edu/index.php/mi mbar

Heinich, R., Molenda, M., Russell, J. D., \& Smaldino, S. E. (2002). Instructional Media and Technologies for Learning (7th Ed.). New Jersey: Merill Prentice Hall.

Huck, C. S., Hepler, S., \& Hickman, J. (1987). Children's Literature in The Elementary School (4th ed.). New York: Holt, Rinehart, \& Winston Inc.

Kelemen, D., Emmons, N. A., Seston Schillaci, R., \& Ganea, P. A. (2014). Young Children Can Be Taught Basic Natural Selection Using a PictureStorybook Intervention. Psychological 
Azmil Hasan Lubis \& Muhammad Nur Wangid, Augmented Reality-assisted Picture Storybook...

Science, 25(4), 893-902. doi:10.1177/0956797613516009

Komalasari, K., \& Saripudin, D. (2017). Pendidikan Karakter: Konsep dan Aplikasi Living Values Education. Bandung: Refika Aditama.

Letarte, M.-J., Normandeau, S., \& Allard, J. (2010). Effectiveness of A Parent Training Program "Incredible Years" in A Child Protection Service. Child Abuse \& Neglect, 34(4), 253-261. doi:10.1016/j.chiabu.2009.06.003

Lee, K. (2012). Augmented Reality in Education and Training. Tech Trends, 56 (2), 13-21. doi:10.1007/s11528-0120559-3.

Lickona, T. (1991). Educating for Character: How OurSchool Can Teach Respect and Responsibility. New York: Bantam Books.

Mallet, M. (2010). Choosing and Using Fiction and Nonfiction: A Comperhensive Guide for Teachers and Student Searchers. New York: Roudledge.

Matulka, D. I. (2008). A Picture Book Primer: Understanding and Using Picture Books. Westport: Greenwood Publishing Group Inc.

Mitchell, D. (2003). Children's Literature: An Invitation to The World. Boston: Ablongman.

Munaris. (2011). Pemanfaatan Buku KecilKecil Punya Karya sebagai Bahan Pembelajaran Sastra untuk Pengembangan Karakter. Jurnal Pendidikan Karakter. 1(1). 87-109.

Nucci, L. P., \& Narvaez, D. (2014). Handbook of Moral and Character Education. New York: Roudledge.

Nurjaman, O. K., \& Julia. (2018). Implementasi Pendidikan Karakter Lokal Kasundaan Berbasis Kebijakan SPBS di Kabupaten Sumedang Jawa Barat. Jurnal Mimbar Sekolah Dasar. 5(1). 1-5. DOI: 10.17509/mimbarsd.v5il.9292. http://ejournal.upi.edu/index.php/mi mbar.

O'Shea, P. M. (2011). Augmented Reality ini Education. International Journal of Gaming and Computer-Mediated Simulation, 3(1), 91-93.

Osher, D., Bear, G. G., Sprague, J. R., \& Doyle, W. (2010). How Can We Improve School Discipline? Educational Researcher, 39(1), 48-58. doi:10.3102/0013189×09357618

Saputro, H. B., \& Soeharto. (2015). Pengembangan Media Komik Berbasis Pendidikan Karakter pada Pembelajaran Tematik-Integratif Kelas IV SD. Jurnal Prima Edukasia. 3(1). 6172 .

Setyawan, A., Suwandi, S., \& Slamet, S. Y. (2017). Muatan Pendidikan Karakter dalam Cerita Rakyat di Pacitan. Jurnal Pendidikan Karakter. 7(2). 199-211.

Sheldon, S. B \& Epstein, J. L. 2002. Improving Student Behavior and School Discipline with Family and Community Involvement. Education and Urban Society, 35 (1), 4-26.

Sunaengsih, C. (2016). Pengaruh Media Pembelajaran terhadap Mutu Pembelajaran pada Sekolah Dasar Terakreditasi A. Jurnal Mimbar Sekolah Dasar. 3(2). 183-190. DOI: 10.17509/mimbar-sd.v3i2.4259. http://ejournal.upi.edu/index.php/mi mbar

Tetenbaum, T. J., \& Pearson, J. (1989). The voices in children's literature: The impact of gender on the moral decisions of storybook characters. Sex Roles, 20(7-8), 381-395. doi:10.1007/bf00287998

Woolfolk, A. (2016). Educational Psychology (13th ed.). Boston: Pearson Education Inc. 